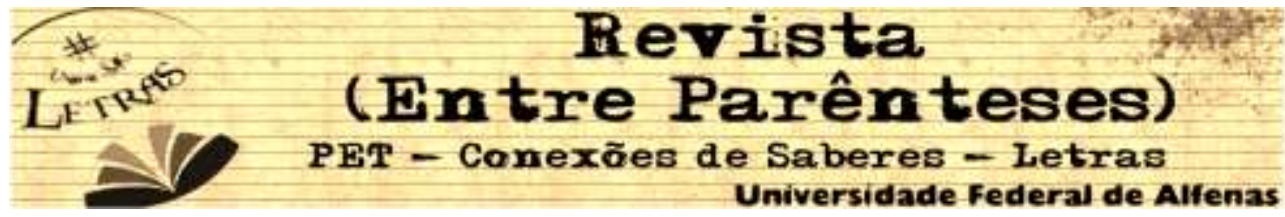

\title{
UMA ANÁLISE DO FUNCIONAMENTO DISCURSIVO DA LEI N. 10.836, DE 9 DE JANEIRO DE 2004, E DO DECRETO N. 5. 209, DE 17 DE SETEMBRO DE 2004: O PROGRAMA BOLSA FAMÍLIA EM QUESTÃO
}

\author{
Leila Maria Franco \\ UEMG- Campus de Frutal ${ }^{1}$ \\ (leilamf@terra.com.br)
}

\begin{abstract}
Resumo: Este estudo objetiva mostrar o discurso do Programa Bolsa Família (PBF), inserido na Política Antipobreza de Transferência de Renda, no governo Lula. A orientação teórica está na Análise do Discurso de Linha Francesa, em Pêcheux (1997), Orlandi (2001a, 2001b). Fundamenta-se, ainda, em questões acerca do discurso político em Pêcheux $(1981,2008)$, Orlandi (2001b). O corpus inclui a Lei n 10.836, de 09 de janeiro de 2004, e o Decreto n 5.209, de 17 de setembro de 2004, o qual regulamenta o Programa Bolsa Família. Ao mostrar o funcionamento discursivo das sequências discursivas, verificamos que o lugar discursivo no material de análise é o do Estado assistencialista: o garantidor, o provedor, no sentido de dar renda (benefício básico, benefício variável) a todos que dele necessitam - os beneficiários; daí a condição de necessitado/assistido pelo Estado. Logo, a forma como a língua foi mobilizada para produzir sentidos na conjuntura sócio histórica já assinala uma orientação, e isso é o político.
\end{abstract}

Palavras-chave: Análise do discurso. Bolsa Família. Discurso Político. Políticas públicas

\begin{abstract}
This study aims to showing the speech of Bolsa Família Program (BFP), inserted in Antipoverty Policy of Income Transfer, in Lula's Government. Theoretical orientation is on Discourse Analysis of French Line, quoted in Pêcheux (1997), Orlandi (2001a, 2001b). It is based, yet, on issues about political speech in Pêcheux $(1981,2008)$, Orlandi $(2001 \mathrm{~b})$. The corpus includes the law no. 10,836 , of January 9, 2004, and the Decree no. 5.209, of September 17, 2004, which regulates the 'Bolsa Familia' Program. By showing the discursive functioning of discursive sequencies, we note that sequences the discursive position in the analysis material is the assistentialist character State: the guarantor, the provider, in the sense of providing income (basic benefit, variable benefit) to all who need it - the beneficiaries; Hence the condition of needy/assisted by the State. Soon, the way the language was mobilized to produce senses in historical social context already indicates an orientation, and that is political.
\end{abstract}

Keywords: Discourse Analysis. Bolsa Família. Political Discourse. Public Policies. Anti-poverty Policy

\section{Introdução}

\footnotetext{
${ }^{1}$ Professora da Universidade do Estado de Minas Gerais - Campus de Frutal. Doutora em Estudos Linguísticos (UNESP/IBILCE); Mestre em Linguística Aplicada aos Estudos da Linguagem (PUCSP)
} 


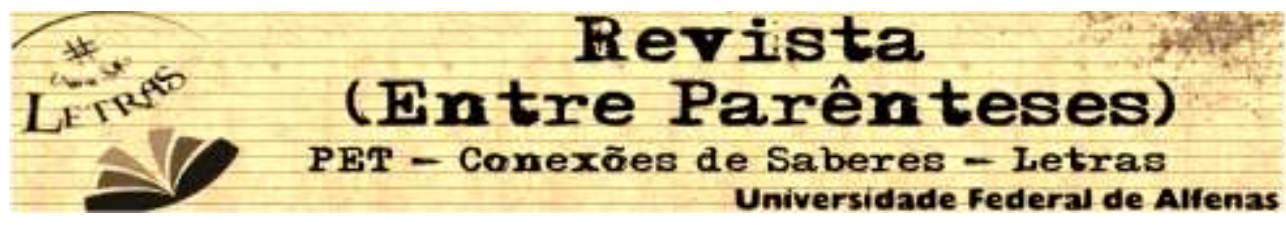

A língua constitui a base material dos processos discursivos, os quais são fortemente articulados com a exterioridade - os processos sócio-históricos e, por isso, mobilizadores da produção de sentido. Digo essas coisas porque é do lugar de analista do discurso que proponho mostrar o discurso do PBF, inserido na Política Antipobreza de Transferência de Renda, na Lei n. 10.836, de 09 de janeiro de 2004, e no Decreto n. 5.209, de 17 de setembro de 2004 que instituem o Programa Bolsa Família $^{2}$ (de agora em diante PBF), implantado no primeiro mandato do governo Lula, mais especificamente no ano de 2003.

Pela sua relação fundamental com o político, a Análise do Discurso (referida a partir de agora como $A D$ ) é o dispositivo teórico escolhido, uma vez que possibilita mostrar as especificidades históricas-políticas, na condição de objetos simbólicos, a fim de questionar os sentidos que tais documentos produzem no contexto histórico de implantação do Programa Bolsa Família e as bases que os sustentam. A perspectiva discursiva, com efeito, possibilita aqui a compreensão dos sentidos inscritos na Lei e no Decreto como objetos linguísticos afetados pelo discurso, ou seja, pelos processos históricos de significação.

A Análise do Discurso tem como objeto próprio de estudo o discurso, definido como "o efeito de sentidos entre locutores" (PÊCHEUX, 1969). Tal definição traz para si as marcas da articulação da língua com a história para significar. No discurso, trabalha-se com as formas materiais (linguístico / estrutura; histórica / acontecimento), formas linguísticas inscritas no mundo, significando os sentidos e os sujeitos e significando-se pelos sujeitos que a praticam (ORLANDI, 2001b, p. 63).

Do lugar da $A D$, falo ainda da língua da ordem material, da opacidade, dos processos de significação que podem se inscrever, na Lei e no Decreto, e da marca da história inscrita nela mesma. É a condição da materialidade para compor o tecido discursivo, o modo como são mobilizados os saberes e o outro. Com efeito, a língua é uma questão política, para tratar do dentro e do fora, do próximo e do ausente, lugar no qual as palavras até podem silenciar-se e, ao silenciarem, abrir espaço para

${ }^{2}$ Bolsa Família será assim grafado, conforme disposto na Lei n. 10.836 de 09 de janeiro de 2004 e no Decreto $n$. 5.209, de 17 de setembro de 2004.

2

Revista (Entre Parênteses)

Volume 1, Número 5, 2016 - ISSN 2238-4502 


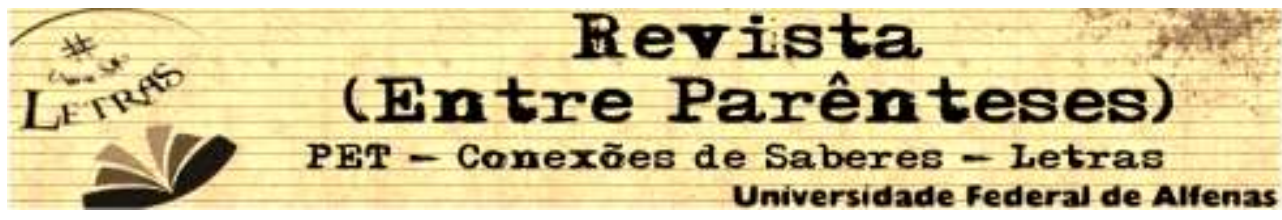

produzir sentidos outros, pois são formuladas em função das posições políticas assumidas no momento em que o dito é dito.

Ao articular o linguístico ao histórico, a AD coloca a língua na relação com os modos de produção social: não há discurso sem sujeito e não há sujeito sem ideologia. Há, entre os diferentes modos de produção social, um modo específico, que é o simbólico. Existem, pois, práticas simbólicas significando o social. A materialidade do simbólico assim concebido é o discurso (ORLANDI, 2001b, p. 63).

O estudo do discurso toma a língua materializada na forma de texto - forma linguístico-histórica. Como consequência, é, no discurso, que se concentram, se intrincam e se confundem as questões relativas à língua, à história e ao sujeito. Nesse sentido, o sujeito - mais especificamente, a posição-sujeito-político - é sujeito à língua e à história, pois, para ganhar existência e produzir sentidos, ele é afetado simultaneamente por elas. Dessa forma, sofre os efeitos do simbólico, pois, se assim não for, não ganha existência, não é sujeito do sentido. Com efeito, os discursos não são fixos, acabados, estão sempre se movendo e sofrendo transformações, acompanhando as mudanças sociais e políticas que integram a vida humana. Logo, como ensina Orlandi (2001a, p. 15), a palavra discurso toma a ideia de curso, de percurso, de movimento. A palavra em movimento, prática de linguagem que se realiza por meio de uma materialidade linguística, pois precisa dela para ter concretude material ou real.

Pensar a língua na relação com o discurso é, então, mostrá-la como lugar da incompletude - um permanente confronto do real da língua com o real da história pois não basta trabalhar apenas o real da língua; é necessário, e definidor no campo da AD, trabalhar com o real da história (ORLANDI, 2001b, p. 39). Ou seja, a língua na sua própria ordem, como sistema significante, sujeita a falhas, deslizes, inscrevendose na história para significar, na produção necessária, o equívoco, o qual traz à luz a verdade do sujeito que enuncia, ao produzir uma falha material que foge ao seu controle. Essa falha materializada na/pela língua não pode ser recoberta, o que possibilita a produção de sentidos outros, que apontam a posição ocupada pelo sujeito discursivo - a do político - assim como as formações discursivas em que seu dizer se 


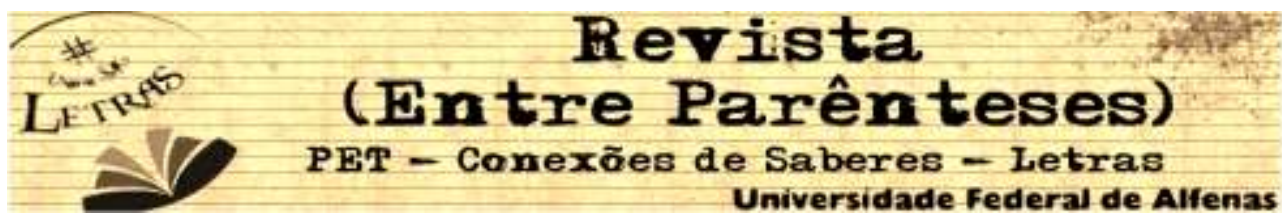

inscreve para produzir determinados efeitos de sentidos. Logo, não é o sujeito que fala a língua, mas, sim, a língua que fala a verdade do sujeito, uma vez que aponta para os vários discursos que legitimam seu dizer.

Se é no interior de questões colocadas pela língua que a exterioridade ecoa, o signo se situa num espaço de interlocução, no qual palavras, expressões ou estruturas sintáticas não são, suficientemente, a garantia de sentido para o texto, pois as condições sócio-históricas de produção de um discurso também são constitutivas de suas significações, razão pela qual a $A D$ tem a exterioridade como necessária no processo de análise discursiva.

Com efeito, ao mostrar o funcionamento discursivo da lei e do decreto que instituem o Programa Bolsa Família, do ponto de vista discursivo, Orlandi (2001b, p. 86) lembra que as palavras não significam em si. Elas significam porque sua interpretação deriva de um discurso que as mantém, que as provê de realidade significativa. Assim, tomo essas palavras para falar da significação, pois "o funcionamento lexical está relacionado com os processos históricos de significação" (NUNES, 2006, p. 150). Nesse caso, remeter o léxico ao sujeito e à história, à compreensão das palavras do discurso (NUNES, 2006, p. 150) e, consequentemente, entender como as palavras foram mobilizadas, a exemplo, pela posição-sujeitopolítico, no contexto do Programa de Transferência de Renda Mínima Bolsa Família.

E o político? Para Pêcheux (1975), o político - o confronto do simbólico com o político - não está só no discurso político, mas está discursivamente presente em todo discurso (ORLANDI, 2012, p. 55), uma vez que os sentidos e os sujeitos são divididos e têm uma direção que não é indiferente à sua relação com a ideologia (ORLANDI, 2012, p. 55). O político se inscreve na divisão dos sujeitos e dos sentidos porque a formação social é regida, pela diferença, pela divisão, pela dispersão discursiva. O político está no fato de que, como a sociedade é dividida, há, pois, uma divisão nos sentidos; eles não significam, com efeito, pelo mesmo, para todos, mas sim, pela diferença. Daí, o equívoco - a incompletude dos sentidos - como funcionamento do político. E o fato de ter um direcionamento, um sentido diferente 


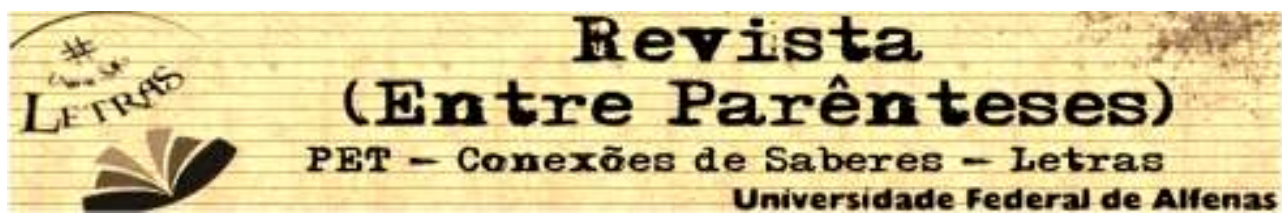

constitui um fato político, e é essa concepção de político que alinharemos nosso estudo.

Nesse sentido, Orlandi (2012) considera o político como dissenso, relação de força que se simboliza, ou, em outras palavras, o político, para a autora, reside no fato de que os sentidos têm direções determinadas pela forma de organização social que se impõe às posições-sujeito que foram interpeladas. Não há forma de estar no discurso sem se constituir em uma posição-sujeito - posição-sujeito-Estado - e sem, portanto, se inscrever em uma ou outra formação discursiva que, por sua vez, é a projeção da ideologia no dizer dessas posições-sujeito.

O político é aqui então compreendido de um ponto de vista discursivo, sendo definido pelo fato de que "o sentido é sempre dividido" (ORLANDI, 2012, p. 55). Essa divisão possui uma direção que não é indiferente às injunções que derivam da forma da sociedade tomada na história em um mundo significado e significante, em que as relações humanas são simbolizadas. Ou seja, uma reflexão sobre o funcionamento discursivo da Lei e do Decreto que instituem o Programa Bolsa Família. Uma reflexão acerca da Língua do Estado, pois representa o pensamento do Estado. Isso porque o discurso político possui uma materialidade linguística e, como consequência, essa materialidade e esse acontecimento são inseparáveis, porque não existe de um lado a linguagem (o dentro) e de outro o histórico (o fora). Eles se fundem para produzir efeitos de sentido que podem assumir um valor eminentemente político. Por outro, porque o discurso é sempre produzido por sujeitos sócio historicamente determinados, condicionados a regras (linguísticas e históricas) que regulam as práticas discursivas.

As proposições teóricas apresentadas conduzem ao estabelecimento dos procedimentos metodológicos que possibilitem a operacionalização do referido aparelho conceptual, com vistas à execução da análise do corpus escolhido para estudo.

Tal objetivo nos conduz, uma vez mais, à teorização, pois, na $A D$, a exaustividade e a completude, mitos tão requeridos nas análises empíricas, são critérios não contemplados. Vale dizer, então, que a Análise do Discurso é uma teoria crítica da produção da linguagem, cujo objetivo é mostrar o funcionamento discursivo 


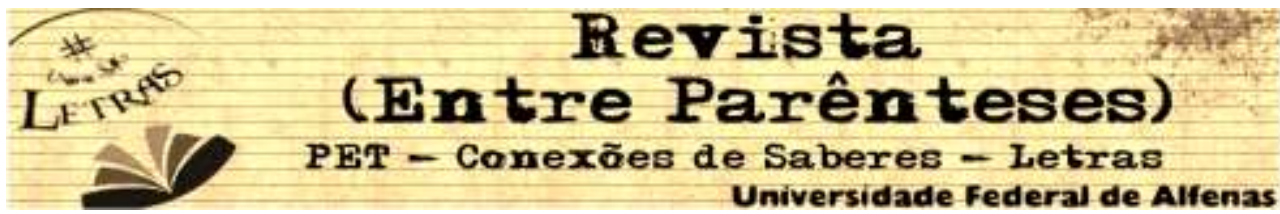

da Lei e do Decreto que instituem o Programa Bolsa Família - as condições de produção do discurso e o contexto histórico-social - nos processos de significação. Com efeito, define-se como método linguístico-histórico-crítico (ORLANDI, 2001b).

A noção de método implica, na $A D$, tanto o dispositivo teórico da interpretação quanto o dispositivo analítico construído a cada análise. O dispositivo teórico é o mesmo, mas o dispositivo analítico não, uma vez que se circunscreve em torno das perguntas de pesquisa propostas aqui, em relação à natureza do material que será analisado e à finalidade do estudo, a saber: (i) Que efeitos de sentido são produzidos na Lei e no Decreto? (ii) Como o Estado significa a si mesmo na instituição do PBF? (iii) Qual a concepção de família nesses documentos e como essa concepção trabalha, supostamente, tanto o deslocamento quanto a fixação de sentidos outros?

Tomemos então esses documentos, para falar sobre o funcionamento dessa discursividade que aí é produzida e que procuramos descrever e compreender, para mostrar os efeitos de sentido produzidos e, simultaneamente, o que fora silenciado/apagado. Então, para mostrar a movimentação desses sentidos nas alocuções discursivas que constituem o nosso corpus de estudo, o movimento de análise iniciou-se pela delimitação das sequências discursivas que comporam o corpus de estudo. E, para mostrar esses sentidos, recorro aos efeitos de sustentação de um mesmo sentido e de silenciamento, enfim, do que caracteriza o campo lexical dessas palavras na conjuntura sócio histórica na qual se inscrevem.

\section{Desenvolvimento}

Passo agora a mostrar o funcionamento discursivo da Lei e do Decreto que instituem o Programa Bolsa Família.

Do ponto de vista do funcionamento discursivo, a Lei cumpre o papel de organização de um sistema de legitimação de um projeto político que fora empreendido pelo Executivo "para garantir os direitos individuais dos cidadãos" (ORLANDI; RODRÍGUES-ALCALÁ, 2004, p. 19). É uma regra de direito com caráter 


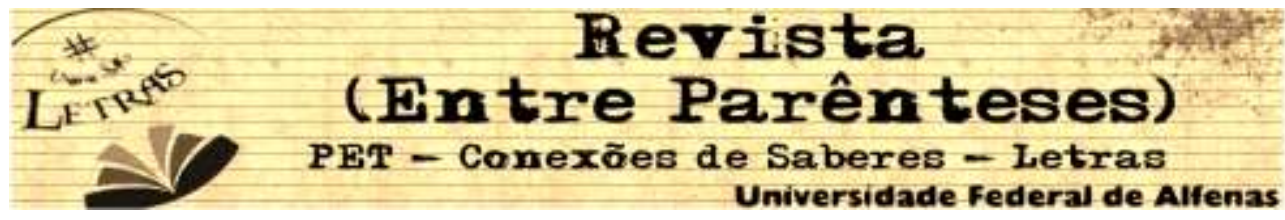

de generalidade e universalidade e, por ter como suporte a língua, está carregada de sentido, que não se desvincula de suas condições de produção. Igualmente, a Lei é expressão do Legislativo, pois visa estabelecer consensos determinados por grupos dominantes da sociedade e serve como instrumento de poder para esses mesmos grupos.

$\mathrm{Na}$ Análise do Discurso, o objeto é o discurso. Tomamos, então, aqui, os discursos da Lei e do Decreto acerca do PBF, para entender como eles são - como produzem sentidos e constituem os sujeitos envolvidos no PBF, a saber: Entes Federados (estados, Distrito Federal, municípios), Gestores e Beneficiários. O estudo analítico do funcionamento discursivo legal pode apontar pistas para as diferentes formas de compreender, então, as posições-sujeito aí inscritas, porque ele emerge e carrega as marcas da conjuntura histórica na sua formulação. Nesse contexto, é preciso, portanto, considerar a ordem da língua, sua materialidade na relação com a materialidade da história. A discursividade é justamente construída nessa inscrição. Aí intervém a interpretação e iniciamos a nossa reflexão propriamente dita, por um lado, para mostrar os efeitos de sentido produzidos neste corpus de estudo e, por outro, o que fora silenciado/apagado.

A Lei n. 10.836, de 9 de janeiro de 2004, institui o discurso do Programa Bolsa Família, que se inscreve na conjuntura histórica, referente ao contexto de política pública brasileira, cuja estratégia é o fortalecimento da agenda de combate à pobreza e a emancipação sustentada das famílias, beneficiárias do programa, que vivem em condições econômicas limitadas, a saber: crianças, nutrizes, adolescentes, gestantes.

Vemos que a discursividade do Programa de Transferência de Renda tematiza suas ações não apenas na seleção das famílias para o recebimento do benefício em dinheiro, mas também ao condicionamento do acesso aos direitos básicos de saúde, educação e aos serviços públicos no sentido de lhes garantir a melhoria da qualidade de vida. Além disso, seria interessante ressaltar que a estratégia discursiva do Estado é enfrentar as consequências advindas da dificuldade de inserção dessas unidades familiares em situação de pobreza e extrema pobreza não apenas no contexto social, econômico, mas também no mercado. A função do 


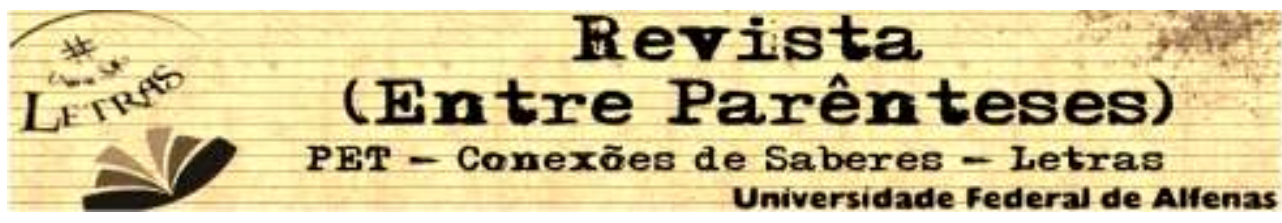

Estado alia-se, então, à do mercado para atender ao bem-comum. Ou melhor, o Estado como regulador das relações sociais a serviço da manutenção das relações capitalistas, no sentido de promover o bem-estar social com dinâmicas que possam aquecer o mercado nas bases de produção e de venda.

Já o Decreto n. 5.209, de 17 de setembro de 2004, explica o funcionamento dessa, ou seja, com o propósito de colocá-la em prática, regulamenta a lei mencionada e traz detalhes acerca da sua aplicação, ao reforçar, igualmente, a exigência/cumprimento de direitos básicos dessas unidades familiares - para minimizar a fome, a pobreza, bem como a desigualdade de renda, que são fatores limitadores de expansão do mercado e da própria estabilização da economia.

A Lei e o Decreto, enquanto objetos de estudo, provocam a produção de sentidos, pois, como nos lembra Orlandi (2001a, p. 31), trazem para o sentido elementos referentes à forma de fazer política, a saber, como as relações sociais são marcadas política e juridicamente no processo de enunciação (em que a posiçãosujeito se marca no que diz), fornecendo-nos pistas para compreendermos o modo como o discurso, que ora pesquisamos, se textualiza. Podemos mostrar isso em função das formações imaginárias - a imagem que é construída do Estado - em suas relações de sentido e de forças (de que lugar fala o governo, por exemplo) por meio dos vestígios que deixam no fio do discurso.

Esses objetos simbólicos, quando se revestem de discursividade, são constitutivos tanto da linguagem quanto do sujeito e, na perspectiva da $A D$, são do tipo autoritário (ORLANDI, 2003), pois é uma norma que se inscreve no discurso jurídico. Jurídico porque se refere a um conjunto de textos que definem a legislação do PBF, por meio dos quais o programa é dado a conhecer. Oferece, destarte, um modo de organização para regular as relações sociais entre o enunciador e os enunciatários que aí estão inscritos: Entes Federados (estados, Distrito Federal, municípios), Gestores e Beneficiários.

Notadamente, na Lei n. 10.836, de 9 de janeiro de 2004, o enunciador é o representante do povo - O PRESIDENTE DA PEPÚBLICA - forma histórico-política de representação do sujeito da discursividade política - inscrita em Faço saber que o 


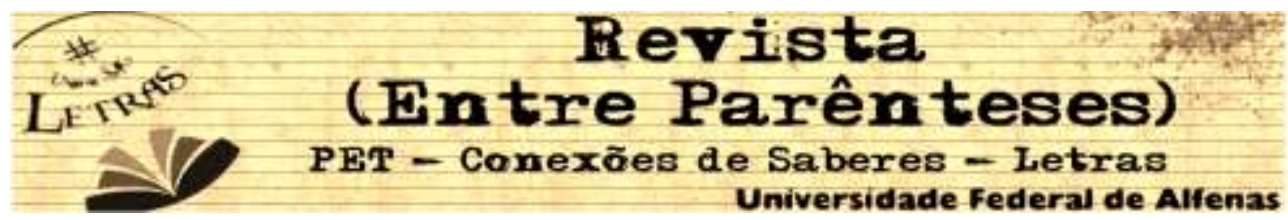

Congresso Nacional decreta e eu sanciono -, para normatizar o funcionamento discursivo dessa em relação a todos aqueles envolvidos, direta e indiretamente, com o Programa de Transferência de Renda e, consequentemente, assegurar sua execução. Forma histórico-política já marcada, já significada, porque fala em nome do Estado: daí "a da prevalência do forte sobre o fraco, [...] a da imposição da ordem para que haja progresso" (ORLANDI, 2012, p. 133).

O seu funcionamento apresenta, pois, caráter subjetivo, observado nas formas verbais de primeira pessoa faz e eu sanciono (BRASILa, 2004, p. 1), que mostram o direcionamento da discursividade, ou seja, o próprio PRESIDENTE DA REPÚBLICA, representante legal, que é institucionalmente reconhecido e posicionado em relação aos outros como a autoridade maior e legítima do Estado num país democrático, previsto, inclusive, conforme disposto no artigo 84 da Constituição Federal (1988, p. 48-49), das atribuições do Presidente da República.

Com efeito, tanto a Lei quanto o Decreto versam um discurso sobre a responsabilidade do Estado e a legitimidade de sua intervenção para organizar, sob o seu controle, a política pública de transferência de renda com condicionantes à saúde e à educação, em particular.

Quando o sujeito PRESIDENTE DA REPÚBLICA toma a palavra, um funcionamento discursivo é mobilizado, definido por ORLANDI (1983, p. 53) como a "atividade estruturante de um discurso determinado por um falante determinado para um interlocutor determinado com finalidades específicas. Determinado aqui remete à posição-sujeito no Discurso" (ORLANDI, 1983, p. 141).

Como resultado, a posição-sujeito-presidente, na cena enunciativa, é a do sujeito de direito - aquele a quem se dá e de quem se cobra a palavra política ou a prática política -, uma vez que enuncia sob a evidência do eu. Consequentemente, a sua posição enunciativa está investida de poder político que, como sujeito discursivo, dita a lei, assegurando-se do consentimento da instância cidadã.

Nesse sentido, o Estado, ao colocar em funcionamento a instituição, distribui tarefas, papéis e responsabilidades que se inscrevem na autoridade, com poder de 


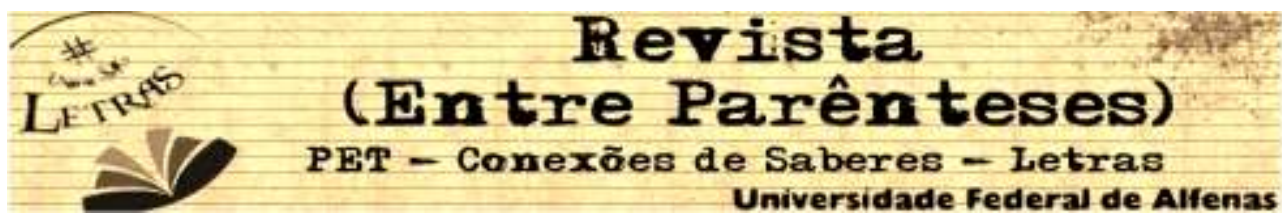

ditá-la. A autoridade - O PRESIDENTE DA REPÚBLICA -, sob a aparência da legalidade, define àqueles a quem se dirige a saberem os seus direitos e deveres.

Diante disso, examinemos o funcionamento discursivo da Lei e do Decreto, detalhando os efeitos de sentido que os determinam. Apoiamo-nos, para isso, na afirmação que permeará a nossa análise: "o instrumento da prática política é o discurso, ou mais precisamente, que a prática política tem como função, pelo discurso, transformar as relações sociais reformulando a demanda social" (HENRY, 1990, p. 24).

Com efeito, não é o discurso que é político, mas as condições de produção que o determinam e, consequentemente, o politiza. Quando disso, a discursividade política é constitutiva do político, pois resulta de uma prática discursiva de sujeitos que participam da cena enunciativa e deixam mostrar um propósito político, cujo desafio consiste em influenciar as opiniões para obter consensos e dissensos. Nasce, assim, o exercício do poder político, que consiste em ditar a Lei e sancioná-la, sempre se assegurando do consentimento ou não da instância cidadã.

Comecemos, pois, pelas finalidades do Programa de Transferência de Renda. $\mathrm{Na}$ ordenação dessas, são bastante frequentes enunciados que determinam a esfera do fazer, recorrente nos verbos no infinitivo. Vejamos, por exemplo, as sequências: Ipromover o acesso à rede de serviços públicos, em especial, de saúde, educação e assistência social; II- combater a fome e promover a segurança alimentar e nutricional; III- estimular a emancipação sustentada das famílias que vivem em situação de pobreza e extrema pobreza; IV-combater a pobreza; $V$-promover a intersetorialidade, a complementaridade e a sinergia das ações sociais no poder público (BRASILb, 2004, p. 2).

No funcionamento discursivo acima, as marcas linguísticas combater, promover e estimular já mostram que os efeitos de sentido são antagônicos. Combater está para opor-se a, sustentar combate contra e, por outro, promover e estimular, em relação sinonímica, está para favorecer algo, provocar, incitar.

Vemos que os complementos dessas formas verbais são dotados também de discursividade. Em combater para dizer que pobreza e fome são inimigos do 


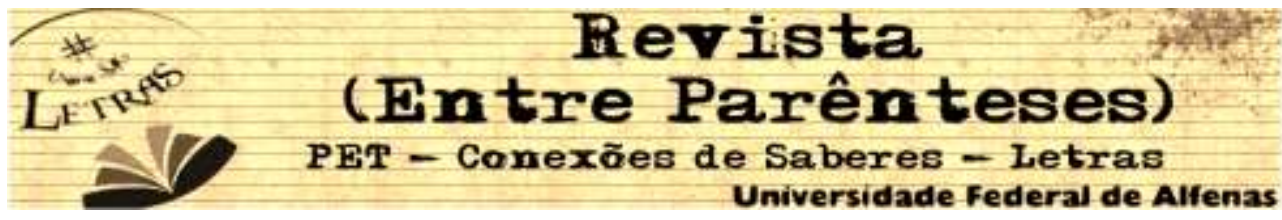

Estado/mercado e, para que isso possa ser erradicado, a proposta do Estado é a de promover e estimular ações políticas que possam organizar a vida das pessoas em sociedade, a exemplo, o acesso à rede de serviços públicos - com vistas a minimizar e mesmo tentar estabelecer relações menos desiguais entre segmentos sociais diferentes. Discursivamente, isso implica laços sociais - a sinergia - entre o Estado e o povo, tempos de paz. O que, pela política, o Estado tenta é, com efeito, evitar as rupturas, as revoluções, as massas (ORLANDI, 2012, p. 127). Legisla, assim, mediante a promulgação de leis e decretos, orientando ações para assegurar/promover possivelmente a inclusão no mercado de unidades familiares em situação de pobreza e extrema pobreza.

A redução da pobreza e o aumento da renda é a motivação dessa política pública. No entanto, o foco na assistência social, saúde e educação reforça a exigência/cumprimento de direitos básicos às unidades familiares que deveriam ser obrigatoriamente garantidos pelo Estado. Aliás, isso evoca uma memória, a memória da Constituição da República Federativa do Brasil de 1988, no seu Art. $5^{\circ 3}$, quando afirma que "todos são iguais perante a lei, sem distinção de qualquer natureza, garantindo-se aos brasileiros [...] residentes no País a inviolabilidade do direito à vida, à liberdade, à igualdade, à segurança, e à propriedade".

Vemos que, na formulação todos são iguais perante a lei, dois efeitos de sentido se inscrevem: um para afirmar a igualdade entre os homens e, como resultado, uma memória jurídica produz um efeito de pré-construído: diante da lei supõem-se que todos sejam iguais. Por outro, opor-se ao dito na Lei e no Decreto que institucionalizam o Programa de Transferência de Renda, uma vez que o acesso passa a ser diferenciado não por direito de cidadania, mas pelo fato de a unidade familiar ser escolhida porque é pobre ou mais pobre do que outra, o que, com efeito, significa ferir noções de direito, cidadania e universalidade que uma política pública deve almejar sem distinções, conforme determina a Constituição, reforçado no pronome indefinido todos e no sintagma nominal são iguais.

${ }^{3}$ Disponível em: http://www.planalto.gov.br/ccivil_03/constituição/constitui\%A7ao.htm.

11

Revista (Entre Parênteses)

Volume 1, Número 5, 2016 - ISSN 2238-4502 


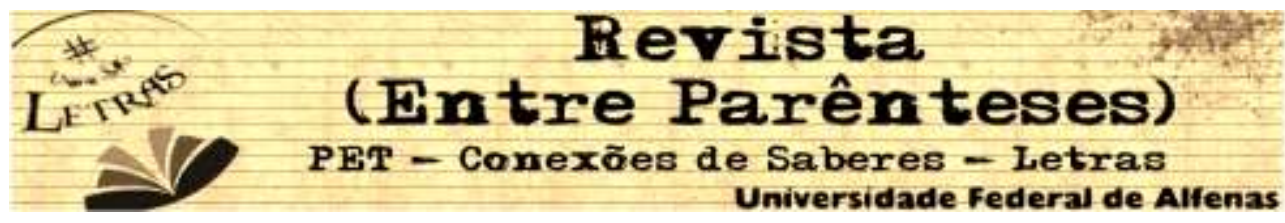

A esse respeito, notamos que a materialidade linguística leva em conta a especificidade histórico-política no contexto em que a focalização - pobre ou mais pobre - tem sido a tendência no desenho dessa política pública, em oposição à proposta universalista - todos, que reforça o modelo econômico do Neoliberalismo, do alguns - da focalização (em situação de pobreza e extrema pobreza) para - a universalização - todos.

Vemos então que o Estado adotou o método da atuação focalizada para atender aos comprovadamente pobres, os quais devem ser obrigatoriamente cadastrados e identificados como pobres - de renda - para terem acesso aos benefícios do Estado. Ao escolher essas unidades familiares, notadamente, temos a inscrição do modelo Neoliberalista, ou seja, o deslocamento do todos para o alguns. O resto do capitalismo é o alguns do Estado, de que ele precisa dar conta por políticas públicas e assistencialistas. Esse resto não faz parte da sociedade de mercado, por definição, está fora (ORLANDI, 2012, p. 224) e, estando fora, tem uma condição de não existência. Daí construir um imaginário de acesso à riqueza e aos bens e serviços socialmente produzidos a esse recorte da população.

O todos e o alguns não ficam visíveis justamente devido a esse apagamento/silenciamento. Apagamento das condições de produção - as possibilidades de coexistência desse alguns (unidades familiares) - que não coincidem quando se pensa a quem o Estado está se dirigindo e que existe a possibilidade, a necessidade de fazer isso, deixando de dizer todo o resto.

Resta ao Estado a fatia que, ao mesmo tempo em que minora minimamente, reforça o sistema capitalista. É o que Jaccoud e Cardoso (2005) denominam de caráter residual, que consiste na incapacidade dessa política pública de atingir efetivamente a todos os que dela necessitam, ficando ainda de fora parcelas significativas de pessoas pobres.

Com efeito, a elegibilidade do programa descontrói o direito universal todos e legitima a ideia de seletividade e de assistencialismo alguns - as unidades familiares - o que só reafirma o paradigma Neoliberal. Ao focar as unidades familiares, o programa afirma que a causa do problema da desigualdade social - da fome e da 


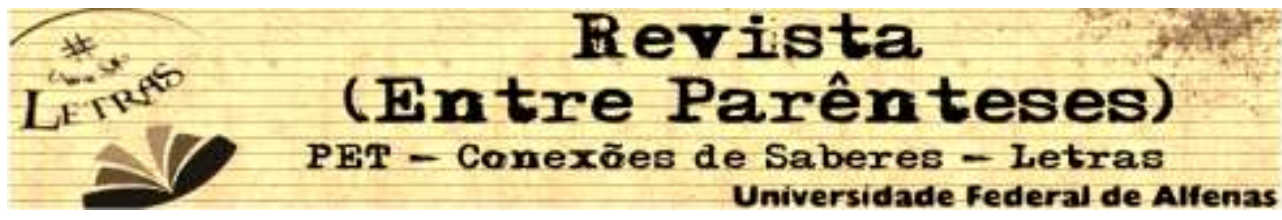

pobreza - está no indivíduo e não no modo de produção capitalista, e isso desencadeia 0 isolamento dos indivíduos para lutarem pela sobrevivência deles próprios, o que os despolitiza como sujeitos históricos e desmobiliza a sua capacidade de lutar coletivamente - a luta de classes, pelas massas.

Um aspecto bastante inovador na legislação do PBF é a família como unidade de intervenção, ou seja, a unidade familiar como lugar de proteção social. Considerando as transformações recentes na configuração das famílias brasileiras, o PBF procura incorporar um conceito mais amplo de família, o qual rompe com os préconstruídos tradicionais de família nuclear como instituição social definida por laços de parentesco, de aliança, deslocando-o para um núcleo de convivência, unido por laços afetivos, compartilhando o mesmo teto, como descrito na Lei 10836, de 9 de janeiro de 2004 Art. $2^{\circ}$, parágrafo $1^{\circ}$, inciso I: Família, a unidade familiar, eventualmente ampliada por outros indivíduos que com ela possuam laços de parentesco ou de afinidade, que forme um grupo doméstico vivendo sob o mesmo teto e que se mantém pela contribuição de seus membros. (BRASILa, 2006).

Aqui, o nome família, na lei, equivalente a unidades familiares, é reformulado com outra acepção. Chama-nos atenção, na definição do sintagma nominal unidades familiares, o advérbio eventualmente para falar das famílias que se unem por laços casuais, fortuitos, num mesmo teto, num mesmo grupo/contexto doméstico, sem a celebração de uma autoridade religiosa.

Essa nova significação, reforçada pelas paráfrases laços casuais, fortuitos, desestabiliza os sentidos, sedimentados, cristalizados socialmente, uma vez que não pressupõe apenas grau de parentesco pessoas do mesmo sangue, tampouco uma ordem legítima, um sacramento instituído por ordem religiosa (laços matrimoniais).

Família na lei retoma a necessidade de habitação, abrigo (teto), lugar de proteção. No entanto, o que determina a constituição de família, na lei, é o critério econômico. Constitui, assim, uma família até que todos tenham parte numa despesa comum do grupo doméstico, habitando o mesmo teto, para o bom andamento daquela unidade familiar. $O$ caráter efêmero das relações nas unidades familiares é reforçado 


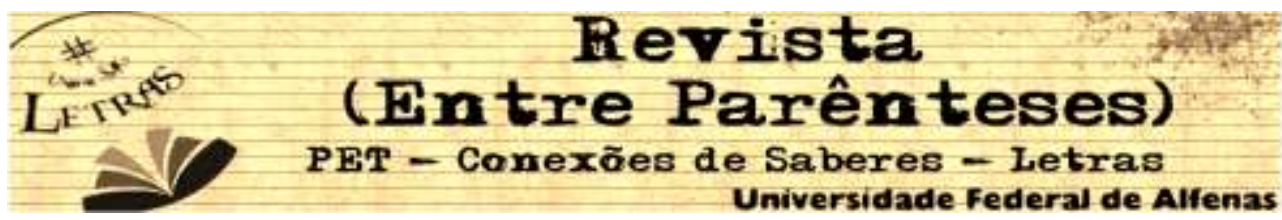

quando um dos membros não mais contribui financeiramente, seja por motivos de desemprego, separação, perda de poder aquisitivo, status, entre outros.

Com efeito, o nome contribuição remete à família, como grupo, como realização de uma função econômica, sob a perspectiva da reprodução da força de trabalho, haja vista que sugere que cada membro dessa unidade familiar contribui igualmente com as despesas da família para determinados fins: alimentação, vestuário, educação.

Assim, no encontro de uma memória e o espaço da sua atualidade, na Lei e no Decreto, o sentido não é fixo, mas movediço e inesperado, resultado de práticas de reelaboração inscritas nas práticas sócio históricas.

Interessante observar que tanto a Lei quanto o Decreto produzem um silenciamento acerca da inserção das unidades familiares no mercado: o fato de elas não se constituírem no espaço da cidade como sujeitos do mundo do trabalho, mas sempre associadas à renda.

A esse respeito, a almejada emancipação sustentada das unidades familiares sugere falta de oferta de programas de geração de emprego e renda. Ou seja, há como um apagamento, delineado pela língua do Estado, nesses documentos, no sentido de minimizar as causas que poderiam justificar a não inclusão das unidades familiares, no mercado de trabalho, a não ser pela destinação de renda. Sobre isso, examinemos as sequências discursivas: I - o benefício básico, destinado a unidades familiares que se encontrem em situação de extrema pobreza. II - o benefício variável, destinado a unidades familiares que se encontrem em situação de pobreza e extrema pobreza [...]; $\$ 3^{\circ}$ serão concedidos a famílias com renda familiar mensal per capita de até $R \$ 120,00$ (cento e vinte reais), dependendo de sua composição. ; A família [...] receberá exclusivamente os benefícios a que se referem os incisos II e III do caput desde artigo[...] (BRASILa, 2004, p. 2).

Podemos verificar que o efeito de sentido dessas sequências está diretamente relacionado com a identificação das marcas discursivas nelas contidas. A esse respeito, associar aqui família à renda significa, em princípio, apontar para a posiçãosujeito-beneficiário que vem historicamente desassistida pelo Estado, além, é claro, 


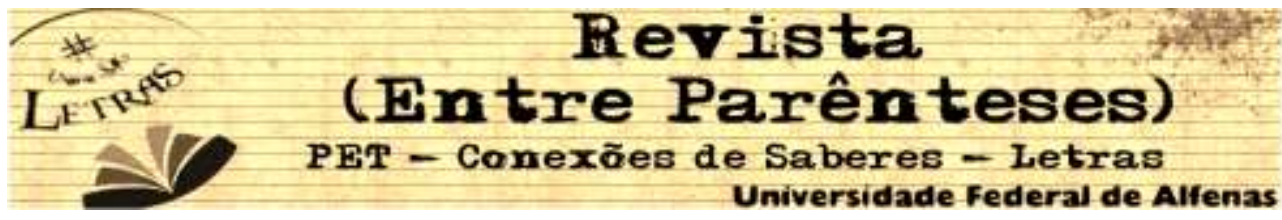

de deslocar a questão para a discursividade econômica, no sentido de garantir um bem, uma posse a essa posição-sujeito.

Daí, a ampla recorrência do nome benefício (benefício básico, benefício variável), o qual mostra exatamente o Estado dando, provendo - para conceder proteção - segurança financeira às unidades familiares com renda familiar mensal per capita entre $R \$ 70,01$ a $R \$ 140,00$, parcela da população vulnerável socialmente. Em que isso pese, no âmbito das políticas públicas e de bem-estar social do Estado neoliberal, o Estado parece intervir minimamente no sentido de garantir o mínimo para a população mais carente. Dessa forma, a Política de Transferência de Renda inscreve-se na perspectiva do Estado Mínimo, no qual o Estado neoliberal se constitui como mero "garantidor/ provedor" de uma renda mínima (benefício básico, benefício variável) às unidades familiares em situação de pobreza e extrema pobreza.

Como é possível ainda verificar a partir dessas sequências discursivas recortadas, o processo de significação das formas verbais destinado a, serão concedidos, receberá é atravessado de discursividade e confere uma orientação argumentativa ao texto, pois determina o efeito de sentido de que as unidades familiares, como complementos, estão destinadas a fiéis depositárias da ajuda/proteção do Estado.

Daí parece decorrer uma relação de natureza mercantil, porque a unidade familiar em situação de pobreza e extrema pobreza deixa de ser aquela portadora de direitos e deveres sociais, para se tornar uma consumidora a quem o Estado transfere benefícios subordinados a critérios de condicionalidades. O objetivo de uma política dessa natureza seria garantir o pagamento da dívida pública de um Estado - culpado - em políticas públicas outras, negadoras dos direitos universais, da seguridade e da assistência social públicas, conforme está prescrito na Constituição da República Federativa o Brasil de 1988. Daí, o que é de direito é transformado, então, em assistencialismo em uma tentativa de minimizar o que o Estado deixou de fazer na oferta de emprego e cidadania.

Acerca ainda do benefício concedido pelo Estado às unidades familiares, na Lei e no Decreto, esse se associa ao cumprimento de algumas condicionalidades. 


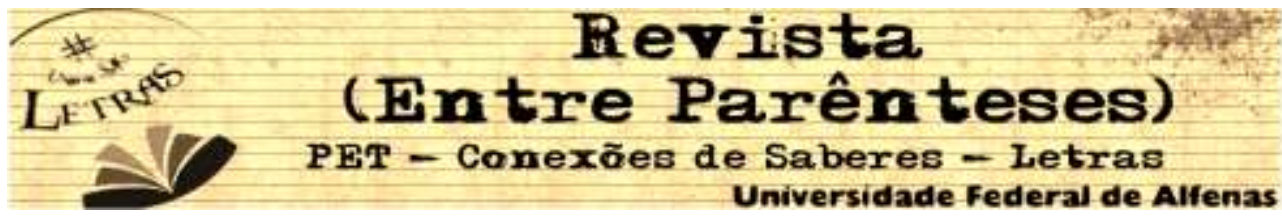

Vejamos as sequências discursivas: Art. $3^{\circ} A$ concessão dos benefícios dependerá [...], de condicionalidades relativas ao exame pré-natal, ao acompanhamento nutricional, ao acompanhamento de saúde, à frequência escolar de 85\% (oitenta e cinco por cento) (BRASILa, 2004, p. 3); Art. 27 Considera-se como condicionalidades do Programa Bolsa Família a participação efetiva das famílias no processo educacional e nos programas de saúde que promovam a melhoria das condições de vida na perspectiva da inclusão social (BRASILb, 2004, p. 9).

No tocante à utilização de mecanismos linguísticos para instaurar a discursividade, o envolvimento das unidades familiares é conclamado, na legislação, no sintagma nominal participação efetiva, a qual define o cumprimento das condicionalidades, que, quando observadas, configuram a porta de saída do programa. Esta passagem é anunciada na formulação que promovam a melhoria das condições de vida na perspectiva da inclusão social. Nesse sentido, dados os tempos de ofensiva neoliberal, essa formulação acaba por reforçar o papel atribuído, por exemplo, à educação - frequência escolar de 85\% (oitenta e cinco por cento) - pela ideologia neoliberal como mecanismo de igualdade de oportunidades. Tal vinculação, ao retomar os pressupostos ideológicos, sugere que a responsabilidade de inclusão social em um país se resolveria mediante a passagem de todos pela escola, com políticas educativas adequadas. O papel social que o Neoliberalismo reservara à educação fora justamente de sua constituição como instrumento de ascensão social e equalização de oportunidades.

Trata-se aqui de uma incisiva que acrescenta um ponto de vista: de que, por meio do alívio à pobreza proporcionado não só pela transferência de renda, mas também pelo acompanhamento educacional, médico e nutricional, pode-se fomentar, na unidade familiar e, em especial nas crianças e adolescentes, capacidades para o exercício da cidadania e da sua respectiva inclusão no mercado.

Discursivamente, não somente o envolvimento da família é conclamado, mas também o do Estado, no sentido de cumprir o seu papel no quesito condicionalidade e, consequentemente, garantir a promoção da justiça social - a porta de saída - para obtenção de emprego e de renda. Sobre isso, vejamos as sequências discursivas: 


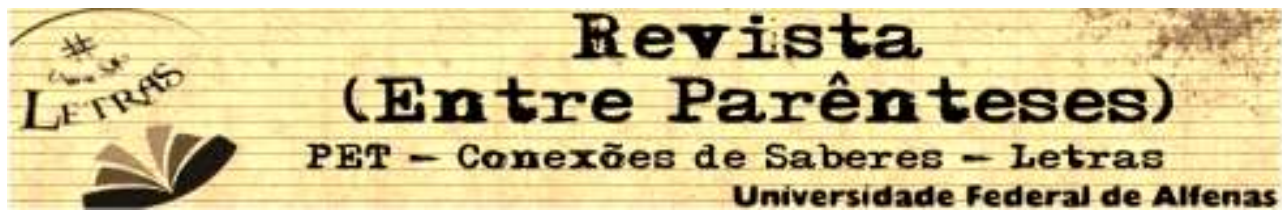

Parágrafo único. Caberá aos diversos níveis de governo a garantia do direito de acesso pleno aos serviços educacionais e de saúde, que viabilizem o cumprimento das condicionalidades [...]. Art. 28. São responsáveis pelo acompanhamento e fiscalização do cumprimento das condicionalidades vinculadas ao Programa Bolsa Família; I- O Ministério da saúde, no que diz respeito ao acompanhamento do crescimento e desenvolvimento infantil, da assistência ao pré-natal e ao puerpério, da vacinação, bem como da vigilância alimentar e nutricional das crianças menores de sete anos; II- O Ministério da Educação, no que diz respeito à frequência mínima de oitenta e cinco por cento da carga horária escolar mensal [...] de crianças e adolescentes de seis a quinze anos (BRASILb, 2004, p. 9).

No sintagma nominal diversos níveis, o Estado igualmente conclama, no seu funcionamento discursivo, a força conjunta dos Ministérios do Desenvolvimento Social e Combate à Fome (MDS), da Saúde e da Educação, no acompanhamento das condicionalidades do Programa de Transferência de Renda, para garantir acesso pleno às famílias beneficiárias aos serviços educacionais e de saúde.

O nome garantia e seu respectivo complemento nominal - direito de acesso pleno aos serviços educacionais e de saúde -, vistos sob a ótica do funcionamento do discurso, discursivizam acerca da ação do Estado na prestação desses serviços. Em outras palavras, o Estado neoliberal pretende intervir, minimamente, no sentido de garantir o mínimo para as unidades familiares - garantir ao menos condições mínimas de educação e saúde. Com efeito, deixam-se de dizer outros sentidos possíveis - falta de moradia, saneamento básico, inserção no mercado de trabalho , embora isso possa contribuir para ampliar o acesso dos beneficiários a serviços que ora não foram incluídos.

No modelo econômico neoliberal, resta ao Estado a fatia (benefício, o acesso aos serviços educacionais e de saúde) que, ao mesmo tempo em que reduz minimamente a condição dos assistidos, tende a reforçar o próprio sistema capitalista, uma vez que o Neoliberalismo é um modo de formação capitalista. Tem-se, então, uma política de inserção de novos consumidores no mercado, mesmo que mínimo de consumo, mas como propulsor das novas bases econômicas. 


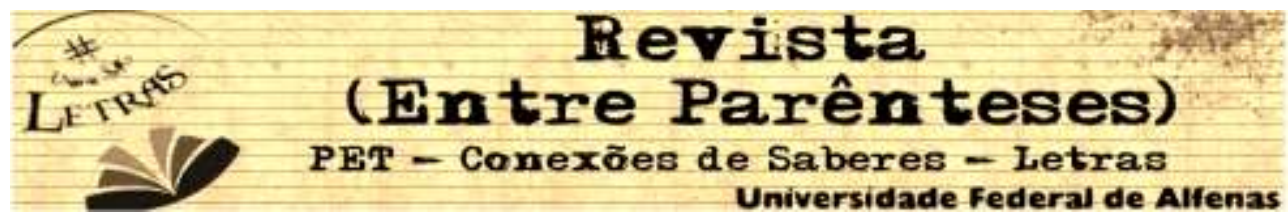

Um aspecto a observar é que, apesar de a legislação ser clara quanto às competências dos entes federados: estados, Distrito Federal e municípios no sentido de promover [...] o acompanhamento do cumprimento das condicionalidades (BRASILb, 2004, p. 4), a cobrança acerca da responsabilidade de gestão e acompanhamento no cumprimento das obrigações das famílias é dos municípios, conforme anunciado no circunstante adverbial em âmbito local e no complemento nominal pelo município, na sequência discursiva a seguir: Art. 29. O controle e participação social do Programa Bolsa Família deverão ser realizados, em âmbito local [...] (BRASILb, 2004, p. 10)

A esse respeito, são questionáveis, aqui, as reais condições e a própria capacidade, no caso dos municípios, em acesso pleno, de ofertarem o que de básico está previsto com relação aos direitos sociais, isto é, os serviços educacionais e de saúde.

Com efeito, é facultada a responsabilidade, o controle e a participação dos municípios e do Distrito Federal para o bom andamento do Programa de Transferência de Renda, no sentido de manter atualizado o sistema de informação e ofertar serviços relativos às condicionalidades.

Quanto à institucionalização do PBF, ela resulta, como já visto, da ação coordenada entre estados, Distrito Federal e municípios e outros setores governamentais e não governamentais. Vejamos sobre isso a sequência discursiva: Art. 11. A execução e gestão do Programa Bolsa Família dar-se-á de forma descentralizada, por meio da conjugação de esforços entre os entes federados, observada a intersetorialidade, a participação comunitária e o controle social (BRASILb, 2004, p. 3).

Notamos que, no sintagma forma descentralizada, o nome forma anuncia como o programa se apresenta, em descentralizada. Nesse sentido, além de descentralizada, a nominalização intersetorialidade é u'a máxima que determinam o processo de implementação do programa de transferência de renda.

Descentralizada, porque tende a democratizar o envolvimento do ente federado que mais se aproxima dos beneficiários - a exemplo: as prefeituras -, 


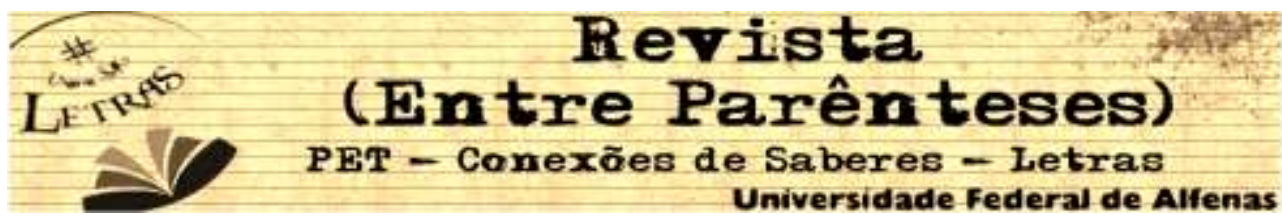

concedendo-Ihes poder de decisão e, consequentemente, ampliando o seu envolvimento na gestão do Programa. Notadamente, a descentralização constitui uma dinâmica política que se inscreve na discursividade do modelo econômico neoliberal, o qual prega o desmonte do Estado como alternativa à gestão da política pública de transferência de renda nos municípios.

Já intersetorialidade se apresenta como instrumento de implementação dessa política pública, na qual responsabilidades e recursos são compartilhados entre estados, Distrito Federal e municípios, para construir uma rede de cooperação social e garantir a oferta de direitos sociais - saúde, educação, segurança alimentar - e criar situações favoráveis à participação social no processo de implementação e execução do PBF. No entanto, tal participação não é discursivizada para informar como será feita e qual a sua natureza.

O Estado aqui se apresenta então como o responsável por fazer incluir a posição-sujeito-beneficiário por meio de políticas públicas, o que é afetado pelo imaginário de pertencimento de um espaço coletivo homogêneo, ao jeito do discurso Neoliberal. Tanto isso é verdade que, apesar de falar do lugar do Estado, desloca a questão para um viés descentralizado - da conjunção de esforços entre os entes federados (público), observada a intersetorialidade, a participação comunitária (privado). No entanto, de início, um primeiro equívoco se apresenta na Lei/Decreto quando esse faz a escolha do público alvo - unidades familiares em situação de pobreza e extrema pobreza com renda mensal per capita entre $R \$ 70,01$ e $R \$ 140,00$. Vemos, aqui, que a seleção é excludente, uma vez que viola a lógica dos direitos.

Aliás, associar aqui a descentralização das políticas públicas à intersetorialidade constitui, pois, um modelo de gestão pública, sustentada nas bases neoliberais de intervenção mínima do Estado no avanço das políticas públicas. Acerca disso, vejamos o $\S 1^{\circ}$ do art. 11, e com vistas a garantir a efetiva conjugação de esforços entre os entes federados, poderão ser celebrados termos de cooperação entre a União, Estados, Distrito Federal e Municípios, observada [...] a legislação específica relativa a cada um dos programas de que trata o art. 3; $\S 1^{\circ}$ Os termos de cooperação deverão contemplar a realização [...]de programas e políticas sociais 


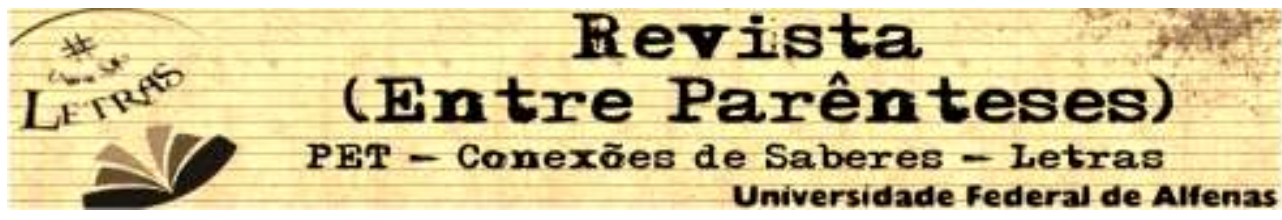

orientadas ao público beneficiário do Programa Bolsa Família que contribuam para a promoção da emancipação sustentada das famílias beneficiárias [...] (BRASILb, 2004, p. 13).

Nas sequências discursivas, as formas verbais poderão ser celebradas e deverão contemplar, seguidas respectivamente de seus complementos - termos de cooperação, a realização [...] de programas orientados ao público beneficiário, emancipação sustentada, garantia de acesso aos serviços públicos -, deixa-se de dizer da natureza dos termos, ou seja, o modo como serão realizados essa emancipação das famílias e o acesso aos serviços públicos na consolidação das políticas sociais. É possível que se silenciem, aqui, direitos que possam vir a ser assegurados pelo Estado aos beneficiários, mas que não estão inscritos no Decreto. Logo, como não está na legislação, não é garantia de cumprimento pelo Estado. Esse silenciamento também é frequente quando define competências aos estados, municípios e Distrito Federal, a exemplo em (BRASILb, 2004, p. 4): I - Promover ações que viabilizem a gestão intersetorial, na esfera estadual, municipal.;/l - Promover ações de sensibilização e articulação com gestores municipais.; III - Disponibilizar serviços e estruturas institucionais, das áreas da assistência social, da educação e da saúde, na esfera estadual.; IV - Estabelecer parcerias com órgãos e instituições do Distrito Federal e federais, governamentais e não governamentais para oferta de programas sociais complementares.

Percebemos aqui estratégias de intervenção do Estado na área social, no entanto, parece faltar clareza na definição delas, inscritas nas formas verbais promover, disponibilizar estabelecer. Também soam frágeis os mecanismos de ação - ações, serviços, estruturas e parcerias, uma vez que não estão claramente especificados. Com efeito, o ponto forte da proposta é a possibilidade de construir uma visão de complexidade dos problemas, tendo, como apoio, a participação de diferentes setores, a exemplo em parcerias com órgãos e instituições do Distrito Federal e federais, governamentais e não governamentais para oferta de programas sociais complementares. Vemos que, ao discursivizar em descentralizada, participação comunitária, instersetorialidade, parcerias [...] governamentais e não 


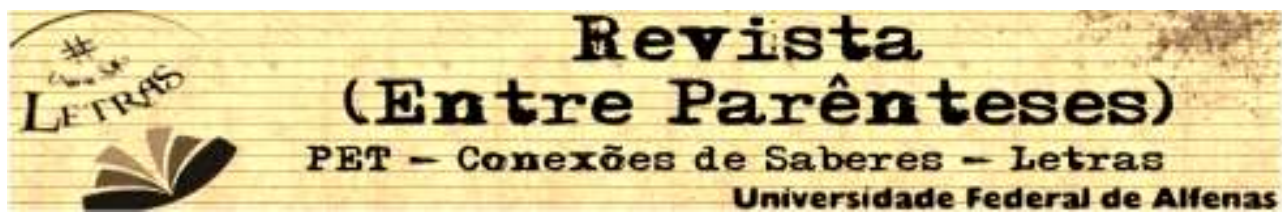

governamentais, inscreve-se a retórica do modelo econômico neoliberal - a retórica das parcerias entre o público (entes federados) e o privado.

Para monitorar a Política de Transferência de Renda às unidades familiares, a legislação institui o controle social que se materializa na participação da sociedade civil na gestão do PBF, no sentido de contribuir para a transparência das ações do Estado e garantir o acesso das famílias vulneráveis ao programa. Vejamos o que determina a Lei na sequência discursiva recortada: Art. $9^{\circ} \mathrm{O}$ controle e a participação social do Programa Bolsa Família serão realizados, em âmbito local, por um conselho ou por um comitê instalado pelo Poder Público municipal, na forma do regulamento. Parágrafo único. A função dos membros do comitê ou do conselho a que se refere o caput é considerada serviço público relevante e não será de nenhuma forma remunerada (BRASILa, 2004, p. 6).

Apesar de a Lei determinar que a fiscalização seja em âmbito local, nos municípios, tende-se a um silenciamento quanto à normalização das ações de controle social. Vejamos na sequência discursiva abaixo: Art. 31. Cabe aos conselhos de controle social do Programa Bolsa Família: I - Acompanhar, avaliar e subsidiar a fiscalização da execução do Programa Bolsa Família, no âmbito municipal e jurisdicional.; II - Acompanhar e estimular a integração e a oferta de outras políticas públicas sociais [...]; III - Acompanhar a oferta [...] dos serviços necessários para a realização das condicionalidades.; IV - Estimular a participação comunitária no controle da execução do Programa Bolsa Família, no âmbito municipal e jurisdicional.; $V$ - Elaborar, aprovar e modificar seu regimento interno.; VI - Exercer outras atribuições estabelecidas em normas complementares do Ministério do Desenvolvimento Social e Combate à Fome.

O nome controle, na administração pública, tem como função fiscalizar e acompanhar se a política pública de transferência de renda não se desvia dos seus objetivos ou das normas que a regem. Nesse sentido, dentre as determinações que o Decreto define para os conselhos acerca do controle social, vemos a significação das formas verbais no infinitivo - acompanhar, avaliar, estimular e exercer.

21 Revista (Entre Parênteses)

Volume 1, Número 5, 2016 - ISSN 2238-4502 


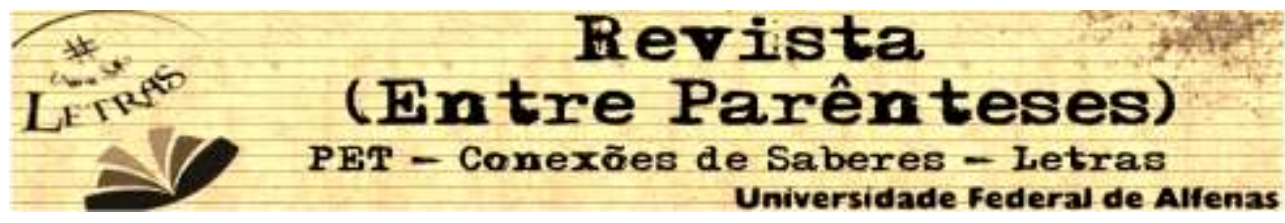

Em acompanhar, avaliar e exercer tem-se o efeito de sentido da ação de velar, vigiar, exercer o exercício do fiscal, cujo complemento é a fiscalização e a oferta de serviços públicos. Já em acompanhar e estimular inscreve-se a discursividade de o estar junto: o Estado companheiro.

Estes conselhos têm caráter deliberativo, cujas atribuições são o acompanhamento, a fiscalização e o gerenciamento da execução do Programa de Transferência de Renda nos municípios. Outro aspecto que merece destaque diz respeito à falta de transparência, por um lado, de como será essa fiscalização, como será a participação comunitária, bem como quais políticas públicas e serviços serão destinados aos beneficiários do PBF.

Por outro, em relação ao processo de responsabilização dos diferentes sujeitos envolvidos por meio de indicação, do gestor municipal do PBF e do Conselho de política pública que responderão pelo acompanhamento do Programa.

Em outras políticas públicas sociais e outras atribuições estabelecidas, o pronome outras contextualiza aqui sua injunção ao histórico, uma vez que revela a incompletude de um número de referentes para outras, que desloca do seu lugar de coisa do mundo para o de quantificador das coisas do mundo que serão constituídas de acordo com a posição-sujeito ocupada na formação social. Tal incompletude tende a abrir espaço para a entrada na cena enunciativa da noção de falta, que é motor do sujeito e lugar no qual as palavras faltam e, ao faltarem, abrem espaços discursivos para a produção de equívocos.

Questionamos também discursivamente a capacidade de gerenciamento dos municípios, no sentido de não responsabilizar as unidades familiares, devido a problemas de gerenciamento e gestão desses na função de oferecer serviços e repassar informações. A esse respeito, a legislação, como veremos a seguir, não prevê penalidades aos municípios inadimplentes, recaindo quase sempre sobre os beneficiários, além, é claro, sobre os agentes públicos a responsabilidade do não cumprimento das condicionalidades. Não responsabilizar os municípios até poderia ser uma estratégia discursiva da parte política no sentido de eximir responsabilidades ou de gestionar os recursos conforme os interesses políticos. 


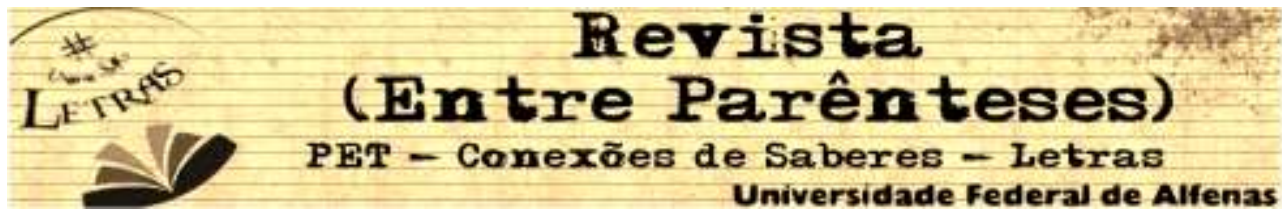

\section{Considerações Finais}

Dado o lugar teórico que nos inscrevemos - A Análise do Discurso -, abrese um lugar privilegiado para compreendermos como os objetos simbólicos - a Lei e o Decreto, a exemplo - produzem sentidos, como eles estão investidos de significância.

O Programa Bolsa Família compartilha um modelo de política pública instituída no contexto da ofensiva neoliberal, da diminuição da função social do Estado, da reestruturação produtiva e da globalização excludente. Com efeito, os efeitos de sentido inscritos nesse corpus de estudo não estão só nas palavras, mas na relação com esse contexto, com esses modos de produção, nas condições em que eles são produzidos e que não dependem, por isso, só das intenções dos sujeitos.

Quando analisamos, na sua formulação jurídica, a Lei e o Decreto e sua constitutividade, notamos como esses textos oficiais vão, cada vez mais, reafirmando a inscrição de um Estado que se mostra o garantidor, o provedor, no sentido de dar renda (benefício básico, benefício variável) a todos que dele necessitam - os beneficiários. Ou seja, à classe de maior vulnerabilidade social e econômica no país - unidades familiares em situação de pobreza e extrema pobreza.

A Lei e o Decreto significam essa posição-sujeito-de direito - o Estado como sendo aquele que não cumpriu o mínimo para prover o cidadão. Daí, o Estado Assistencialista culpado. Aliás, é muito significativo o apagamento que a Lei e o Decreto fazem a esse respeito: apagam as unidades familiares que, historicamente, vêm absolutamente desassistidas. E essa é a grande crueldade da assistência.

O Estado se vê diante dos cidadãos que são colocados na posição de necessitados/ assistidos pelo próprio Estado, e não só do Estado, mas de todo um discurso disponível, por uma história que coloca todos que precisam de assistência - unidades familiares em situação de pobreza e extrema pobreza.

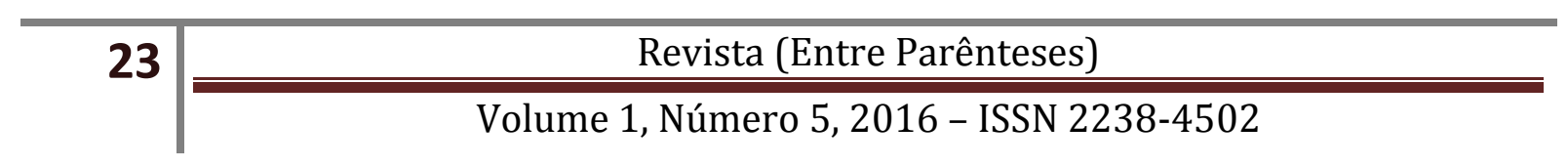




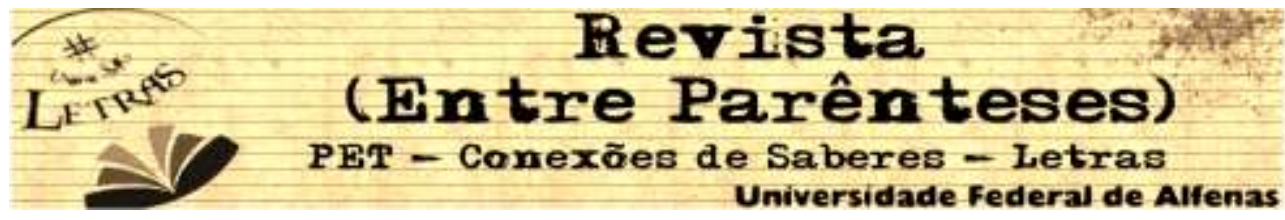

Na forma do 'neocapitalismo' atual (ORLANDI, 2012, p. 233), a falha do Estado como articulador-simbólico para garantir condições de existência aos beneficiários por meio de políticas públicas é estruturante, do sistema capitalista contemporâneo, uma falha necessária para garantir o funcionamento do próprio sistema capitalista. Daí o objetivo - estimular a emancipação sustentada famílias (BRASILb, 2004, p. 2) - parece ser uma ilusão de completude, uma vez que a conclamada autonomia somente existiria quando as unidades familiares tivessem um trabalho, ou seja, estivessem sendo explorados no mercado capitalista. Nesse sentido, o fato da unidade familiar viver do programa de transferência de renda, ou seja, não ser explorado pelo mercado de trabalho capitalista, não se constitui como um elemento emancipatório, mas como uma dependência do Estado. Podemos notar que o argumento apresentado tem uma face extremamente Neoliberal, uma vez que depender do mercado é tido como algo positivo, enquanto depender do Estado é visto como um aspecto negativo, causador de falta de autonomia.

Se a política pública é a ação do Estado em determinado período histórico, definida por um governo constituído como parte das ações que determinam o padrão de proteção social implementado pelo Estado, vemos que a posição-sujeitolegislador, na cena enunciativa - unidades familiares em situação de pobreza e extrema pobreza -, inscreve uma prática discursiva definidora que marca, para nós, leitores, um pacto do Estado com a sociedade civil.

Chama-nos a atenção, na formulação acima, o circustante em situação de, o qual para nós ratifica que o funcionamento discursivo vai pela contradição, divisão, tensão entre grupos sociais diferentes: grupo do ter, do mercado, dos ricos x grupo do não ter, do não mercado, dos pobres. E como isso aparece? - poder-se-ia questionar. A seguir, apresentamos, esquematicamente, a nossa compreensão sobre isso:

\begin{tabular}{|c|c|l|}
\hline $\begin{array}{l}\text { Grupo do ter, do mercado, } \\
\text { dos ricos }\end{array}$ & $\leftarrow$ em situação de & $\begin{array}{l}\text { Grupo do não ter, do não } \\
\text { mercado, dos pobres }\end{array}$ \\
\hline \hline 24 & \multicolumn{2}{|c|}{ Revista (Entre Parênteses) } \\
\cline { 2 - 2 }
\end{tabular}




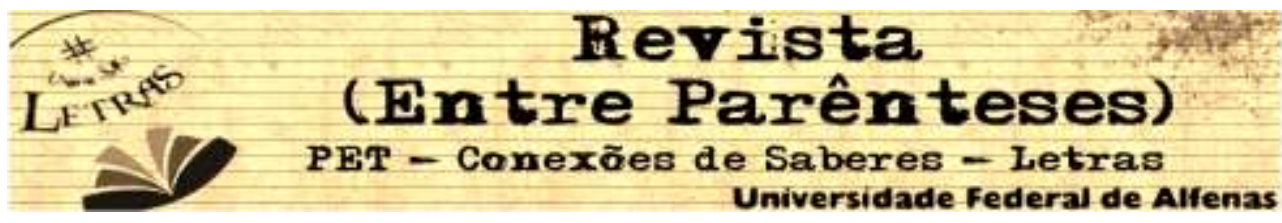

Notadamente dois pontos chamam a atenção: a condição de posse e a condição de estar ou não no mercado. Daí, a ideologia do mais fraco, do mais pobre é sublimarmente construída na discursividade do Estado: o desprovido de renda ou bens. Apesar de a lei escolher trabalhar com esta diversidade - em situação de pobreza -, evita-se falar sobre o pobre, porque este é lugar da diferença, de mobilização social, do não estabilizado, daquilo que, sujeito a equívoco, seria uma possibilidade real de ruptura, da divisão social.

Aborda-se aqui, pois, a questão da pobreza de renda inserida na sociedade industrial moderna - notadamente silenciada/apagada na inadaptação escolar, profissional, nas desigualdades, na falta de assistência médica. Decorre daí que o modo de individualização do sujeito seja questão de competência do Estado, ou melhor, a articulação simbólico-política de que o Estado é responsável, seja pelas instituições, seja pelos discursos, seja pelos indivíduos em situação de pobreza e extrema pobreza. Portanto, há uma língua do Estado, individualizando os sujeitos que são afetados - 'beneficiados' - por ela (Estado).

Logo, apresenta-nos o Estado que ora fora alheio e unilateral, para tentar impedir o desgaste dos laços sociais. Com efeito, espera-se do Programa de Transferência de Renda o resgate de novos laços, novas bases entre o Estado e o povo, em especial, com as unidades familiares em situação de pobreza e extrema pobreza, bem como uma resposta às novas demandas sociais que se impõem. Daí, a tentativa de construir um imaginário menos ameaçado com as parcelas mais vulneráveis da população.

No funcionamento discursivo da Lei e do Decreto, além do discurso de um imaginário igualitarista do Estado em relação às instâncias governadas - unidades familiares em situação de pobreza e extrema pobreza -, o qual apregoa amenizar as condições de vulnerabilidade do ponto de vista socioeconômico que faça com que a família saia do estado de miséria (combater a fome e a pobreza), para assegurar a possibilidade de cada unidade familiar satisfazer, mesmo que minimamente, suas necessidades por renda, bens de consumo, fomentar o mercado consumidor (dar 


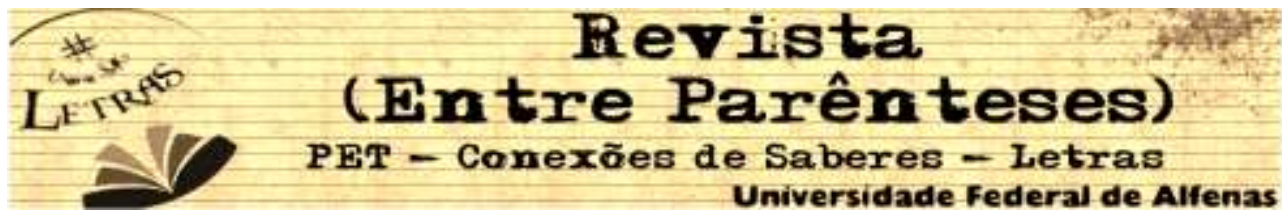

poder de compra), inscreve-se uma discursividade de solidariedade (MAGALHÃES, 2001) como opção à regra de justiça neoliberal.

Isso porque o bem-estar geral depende da participação de todos, e o Estado, apesar de mínimo, assume o papel de "responsável pela materialização da solidariedade através de mecanismos e estratégias próprios de repartição dos bens e serviços sociais" (MAGALHÃES, 2001, p. 3) na tentativa de minimizar a desagregação do tecido social.

Já notamos aqui o Estado que, ao disponibilizar o benefício, induz o consumo - ativador da economia que sustenta novas cadeias produtivas no mercado baseadas no ritmo do comércio local. Além do mais, o discurso da solidariedade - do Estado companheiro, do estar junto (acompanhar e estimular) com os desprovidos - está intimamente ligado ao da igualdade: a ação de repartir um bem (renda) com o outro para ajudá-lo a reencontrar seu lugar na sociedade, em nome de um imaginário comum: a humanidade.

Com efeito, o discurso da cidadania e dos direitos sociais dá lugar ao discurso humanitário da filantropia. Daí o Programa de Transferência de Renda tende a adquirir um perfil seletivo, focalizador, despolitizado, refilantropizado, fundado na solidariedade social, bem ao gosto neoliberal. Diante disso, a política de compensação econômico-financeira entra em pauta como forma de reduzir o problema - um exercício político de solidariedade, uma prática que, diante da divisão, da contradição, assegura uma convivência harmônica e pacífica com o diferente (os indivíduos do não ter, não mercado, pobre) - unidades familiares em situação de pobreza e extrema pobreza.

Isso, em nossa visão, sugere, de algum modo, no imaginário, uma prática de exclusão que, silenciosamente, é afirmada, uma vez que os cidadãos precisam primeiro do direito ao trabalho e, em decorrência, do direito a uma renda; como consequência, é possível que não promova as populações beneficiárias na sua humanidade: oferecer condições de trabalho, de lutar intelectualmente para viver bem na sociedade.

\begin{tabular}{l|c}
\hline $\mathbf{2 6}$ & Revista (Entre Parênteses) \\
\hline \hline Volume 1, Número 5, 2016 - ISSN 2238-4502
\end{tabular}




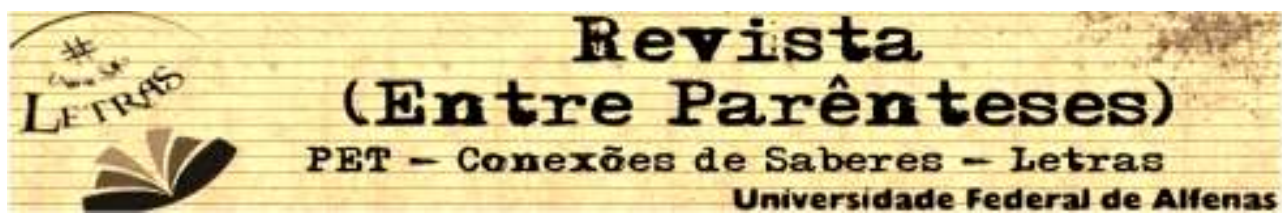

\section{Referências}

BRASIL, Constituição da República Federativa do Brasil de 1988. Disponível em: $<$ http://www.planalto.gov.br/ccivil 03/constituicao/constituicao.htm>. Acesso em: 15 mar. 2012.

BRASIL. Lei n. 10.836, de 9 de janeiro de 2004. Cria o programa bolsa família e dá outras providências. Disponível em: <http://www.planalto.gov.br/ccivil 03/ Ato20042006/2004/Lei/L10.836.htm >. Acesso em: 17 jan. 2010a.

BRASIL. Decreto n. 5. 209, de 17 de setembro de 2004. Regulamenta a Lei n. 10.836, de 9 de janeiro de 2004, que cria o programa bolsa família, e dá outras providências. Disponível

em: $<$ http://www.in.gov.br/imprensa/visualiza/index.jsp?jornal=1\&pagina=3\&data=20/09/2 004>. Acesso em: 17 jan. 2010b.

HARVEY, D. O Neoliberalismo: história e implicações. Trad. Adail Sobral, Maria Stela Gonçalves. 3. ed. São Paulo: Loyola, 2012.

HENRY, P. Construções relativas e articulações discursivas. Trad. João Wanderley Geraldi e Celene Margarida Cruz. Caderno de Estudos Linguísticos, Campinas, (19): 1-179, jul./dez. 1990.

- Os fundamentos teóricos da 'Análise Automática do Discurso' de Michel Pêcheux (1969). In: GADET, Françoise; HAK, Tony (Orgs.) Por uma análise automática do discurso: uma introdução à obra de Michel Pêcheux. Trad. Bethânia S. Mariani et al.. Campinas: Unicamp, 1990.

MAGALHÃES, R. Integração, exclusão e solidariedade no debate contemporâneo sobre as políticas sociais. Cadernos de Saúde Pública, Rio de Janeiro, v.17, n. 13, 2001.

NUNES, J. H. Lexicologia e lexicografia. In: GUIMARÃES, E.; ZOPPI- FONTANA, M. (Orgs.). A palavra e a frase. Campinas, SP: Pontes, 2006, p. 149- 172.

ORLANDI, E.. Interpretação. Petrópolis: Vozes, 1996.

. Análise do discurso: princípios e procedimentos. 3. ed. Campinas, SP: Pontes, 2001a.

Discurso e texto: formulação e circulação dos sentidos. Campinas, SP: Pontes, 2001b. 


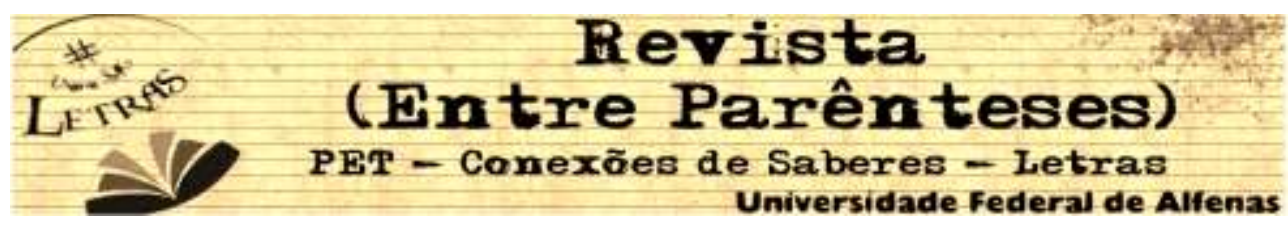

Formas de conhecimento, informação e políticas públicas. ANIMUS, Revista Interamericana de Comunicação Midiática. v. 17, jan. Disponível em: <http://cascavel.ufsm.br/revistas/ojs-2.2.2/index.php/animus/article/view/2373/2458>. Acesso em: 30 maio 2010b.

. (Org.) Discurso e políticas públicas urbanas: a fabricação do consenso. Campinas, SP: RG, 2010a.

Discurso em análise: sujeito, sentido, ideologia. 2. ed. Campinas, SP: Pontes, 2012.

; RODRÍGUEZ-ALCALÁ, C. Produção do consenso nas políticas públicas urbanas: entre o administrativo e o jurídico. Escritos n.. 8 Labeurb/Nudecri/Unicamp, p. 11-23, 2004,

PECHÊUX, M. Analyse automathique du discours. Paris : Dunod, 1969.

PECHÊUX, M. Análise automática do discurso (AAD - 69). In: GADET, F. e HAK, T. Por uma análise automática do discurso: uma introdução à obra de Michel Pêcheux. Campinas, SP : EDUNICAMP, 1990. p. 61-162.

Semântica e discurso: uma crítica à afirmação do óbvio. Trad. Eni Pulccinelli Orlandi. 3. ed. Campinas, SP : Pontes, 1997.

PRESIDÊNCIA DA REPÚBLICA FEDERATIVA DO BRASIL. Fome Zero. Disponível em: <www.fomezero.gov.br/o-que >. Acesso em: 14 set. 2009.

RODRIGUES, M. M. A. Políticas públicas. São Paulo : Publifolha, 2010. 